\title{
Adriana TEODORESCU \\ Dispelling the Ideology of Immortality. Reading Kundera through Critical Theory Lenses
}

\begin{abstract}
The present study aims at analysing the representations of symbolic immortality in Milan Kundera's novel, Immortality (1999), and at assessing their potential to function as a critique of the current ways in which Western society configures immortality based on an over-pacifying principle capable of simulating/recycling an essentialist ontological dimension. The novel deconstructs symbolic immortality, denouncing all positive biases related to it and, consequently, emancipating the reader from the slavery of an ideologized immortality. Kundera's view on immortality is determined, to a great extent, by both acknowledging the key-role of otherness in thinking and symbolically structuring immortality and revealing its culturally idealised nature, the fact that it is one of the (few) structures that still resist to postmodern criticism of sign and meaning. Kundera's grasp of otherness is strongly influenced by Jean-Paul Sartre's negative philosophy of the Other. Critical theory plays an important part in the general approach of this paper in the sense that it makes visible how the novel encourages an interpretation through critical theory lenses.
\end{abstract}

Keywords: symbolic immortality, critical theory, the Other, deconstruction, Kundera, Sartre.

Introduction. The contemporary ideologization of symbolic immortality

The term "symbolic immortality" was first coined by psychiatrist R. J. Lifton $(1974,1979)$ as a psychological and cultural reality generated by the universal human will to nurture a feeling of continuity and transcendence in the face of death (not related to a specific religion). The concept is elusive and under-theorized. For instance, many scholars who followed Lifton consider the contemporary symbolic immortality to be a projection of the human being beyond the limits of life, which can be attained through something different from itself (offspring, nature, etc.). It is, therefore,

\section{Adriana TEODORESCU}

Department of Sociology

Babeș-Bolyai University

adriana.teodorescu@gmail.com

EKPHRASIS, $1 / 2018$

Aftermaths of Critical Theory

pp. $148-170$

DOI:10.24193/ekphrasis.19.11

Published First Online: 2018/06/20 
an acknowledgement of one's own mortality which many times includes a symbolic representation of the existence projected in a space and time following the death of the subject (an after-death existence through something else than the self, a symbol). Yet, for Zygmunt Bauman (1992) (and those inspired by him), symbolic immortality designates a life strategy that includes Lifton's definition and the temporary feeling of postponing death (a before-death immortality) as well. Overall, scholars from social sciences and humanities tend to see symbolic immortality in a positive light (a clear exception: symbolic immortality involved in heroic death if it refers to non-Western areas and terrorism, of course), emphasising rather its universal and psychological (as if psychological could still stand today for authenticity) aspects and ignoring that it is also (massively) subject to social influences, a channel in which social narratives can freely circulate and permeate into individual life stories (Harari 2017) with all their so-called values: romance, positive otherness, cohesive identity, ethically structured future/history, etc.

Today symbolic immortality replaces not only the absolute, spiritual-like immortality, almost indecent now (with the notable exception of technologically mediated immortality) because of its outdated operational truths (and not being in fashion is one of the greatest cultural sins). However, its function is not a passive, limited one, such as staging nostalgia or promoting an aestheticized strategy of reminiscing about losing a full, consciousness-friendly transcendence, but on the contrary, symbolic immortality ${ }^{1}$ becomes a must have, an object of desire - the other face of power, in a Foucauldian perspective - and, thus, there are fights to be fought while, at the same time, the Other, as a general instance, is dialectically disrupted, fragilized: they must ensure symbolic immortality while potentially competing for it. Nevertheless, symbolic immortality can barely hide its postmodern, capitalist ideological character: it is not only inter- and intra-competitive (only the best and the most condensed version of yourself will be allowed to enter the realm of the symbolically transubstantiated post-identity), the symbolical medium is pre-selected (not everything can be an - let us call it like this - immortalical support; the general and the significant Other, art, nature remain highly privileged and are already interpreted in a positive way), the absence, as inherent contributor in the process of constructing meanings of reality is erased (either by purely ignoring death or by downsizing it to the name of an absence) and the whole process is objectified: you will have your symbolic immortality if you deliver yourself to Other.

This study aims to analyse the representations of symbolic immortality in Milan Kundera's novel, Immortality (1999) and to assess their potential to function as a critique of the current ways in which Western society configures immortality based on an over-pacifying principle capable of simulating/recycling an essentialist ontological dimension. Critical theory plays an important part in the general approach of this paper in the sense that, as we will see, the novel encourages an interpretation through critical theory lenses. And this not as a gratuitous interpretative exercise, for two 
reasons. Firstly, because Kundera's representations of immortality (at least in this novel) always go beyond themselves, achieving a sort of lucidity and passion for selfreflection - they cannot be confined to pure literary expressions; they work on the thin line between literature and its opposite term, whatever this term may be - that allow them to speak for and of themselves: they become meta-representations. It is not so much about how immortality is represented, but about how representations of immortality discover the power to question both the world and themselves: they become theoretical - "inherently emancipatory", non-objectifying, anti-positivistic, and reflective - exactly in the sense in which Geuss (1981,2) described critical theory in his book on Frankfurt School and Habermas. Secondly, Kundera's view on immortality is determined, to a great extent, by both acknowledging the key-role of Otherness in thinking and symbolically structuring immortality and revealing its culturally idealised nature, the fact that it is one of the (few) structures that still resist to postmodern criticism of sign and meaning. Kundera's grasp of otherness is obviously strongly influenced by Jean-Paul Sartre's negative philosophy of the Other - which is not the same with affirming that Kundera's aesthetical mechanisms of conceiving the Other are reducible to a Sartrean mechanism² ${ }^{2}$, but which indicates the fascination with the freedom of disagreeing with common sense, the force to fully embrace suspicion and its correlative, the (interpretative) risk. The novel deconstructs symbolic immortality - especially symbolic immortality through art and through others - and shows how immortality narrows from a grand discourse to a personal imagery of the after-life (that I chose to call personalised micro-immortality) used for fantasising - far from any pretence of referential and transcendental certainties and for giving birth to distance in a world where distances and differences lose their verticality, entering the game of permutability and random combinations. If the Other is not reliable (extending Sartre's view) nor even possible (extending a metaphysics that starts crumbling or imploding), it must be invented, saved in the only manner left - artificially, as a sign that must be allowed to betray the source that fantasised it. As it will become evident, micro-immortalities are de-ontologised forms of Otherness.

The deconstruction of symbolic immortality consists in denouncing all positive biases regardless of their roots (cultural, philosophical, religious, artistic, etc.) related to immortality and, therefore, emancipating the reader from the slavery of an ideologized immortality. Nonetheless, the other pole of deconstruction is also respected - what is criticised must endure precisely because what is put into motion is not a structure against another (structures are matter of perspective, not of nature), but the signification as an endless, infinite process (Derrida 1967). Up to a certain point, immortality is inevitable, responding to a psychological and cultural impulse of order and coherence, an impulse always throw into crisis by death. Another way of acknowledging the connection between death and immortality. Repeatedly, Kundera observes that immortality is the other side of death, of human limitation, that death and immortality are inseparable: "death and immortality are an indissoluble pair of 
lovers" (49). Otherwise, in a Derridean-like vein - having here in mind the claim of the French philosopher, in his study on death (1996), that immortality is always a second-hand ontological structure produced by death, which, thus, it cannot escape (not even discursively) - for Kundera immortality contains much more its own negation than its proper meaning. The possibilities of immortality to form its own meanings are already hijacked by death. The problem is that, too often, "man reckons with immortality, and forgets to reckon with death" (74), and, taking advantage from this denial and oblivion of death, society tries to impose its own, round, pacified meanings. There is a double fundamental lack in immortality: it does not have a death-independent meaning, and, death itself can constitute immortality's signified only as an onto-linguistical compromise. In fact, many characters from Immortality will discover, in the middle of their efforts to build a symbolic immortality that fulfils social requirements, nothing more and nothing less than death. Which is different than saying that Kundera proceeds to casting an exclusively positive light on death and mortality - another form of ideology that might be even more fashionable nowadays than immorality that I will not discuss in this article. Practicing immortality after saving it from ideology remains necessary. One of the lessons of Kundera's novel is that although immortality risks to be confiscated semantically, socially and theoretically, if we look carefully, we will see, like a sort of aura, in a glimpse, that sometimes the being as being-towards-death (Heidegger 1962) looks exactly like the being as beings-towards-immortality. Not that we could operate on this discontinuum.

\section{Personalised micro-immortalities}

The syntagma of 'personalised micro-immortality' refers to those representations of symbolic immortality which feature dense imagery and dense narrative compared to standard representations of symbolic immortality. They are projections of postmortem worlds which display a high coherence and in which one consciousness belonging to various characters or to the narrator himself - willingly positions itself in a future perspective, experiences different emotions, and oscillates between total comfort and absolute fear ${ }^{3}$.

Micro-immortalities might be mistaken for representations of absolute immortality, but what truly distinguishes them from the latter category is not so much their personal nature - in the sense that they belong to someone, they are built and directed by a consciousness which projects itself outside life - or their dependency on the imagination which activates them - they do not exist autonomously, independently of the consciousness which triggers them, as it is presumed that absolute immortality backed up by religion or ancestral beliefs exists - but the fact that they are managed by a "fictional pact" (Eco 1994). This pact is signed, on the one hand, by the authorship valence of consciousness - consciousness proposes, invents the micro-world in which the being will dwell after its death, imagistically assembling this world according to its own will and setting its underlying rules and liberty restrictions - and, on the other 
side, by the role of the reader (by extension, the consumer) of the same consciousness (the consciousness as dialectically fractured as writer and reader). In other words, consciousness willingly stages, directs its afterlife reality in order to be able to rejoice (in a cathartic, non-literal sense, as rejoicing is many times an experience of fear), to be able to have access to the things otherwise inaccessible. Such a reality can be understood only as postulate for a construction both in the classical social sense: reality contains nothing natural, preceding the objective transformation of the subjective processes through which the common, joint sense of reality gets intersubjectively constructed (Berger \& Luckmann 1966) and in the postmodern (critical and (self-)seductive) sense: the signs proliferate, but only linearly, as they lost their ability to designate or coagulate reality; construction itself indicates a now obsolete (vertical) paradigm, replaced by an excess of the real, the hyperreality where reality is abundant, but only ghostly, it haunts as it is actually lacking - what Baudrillard (1981) explained as the strategy of simulacra to recreate/simulate the principle of reality.

In addition, the dual nature of consciousness - which triggers, and for which personalised micro-immortality is triggered - makes the fictional pact adjustable to the wishes, temptations or the interests of the consciousness it imaginarily projects. As such, the immortality represented by personalised micro-immortalities is, in spite of its coherence, a trial of immortality, as it is not constant, and it may take many shades (one personalised micro-immortality has many variants, possibilities). The ones imagining micro-immortality never fully forget that they are the authors of this afterlife-constructs and that there is no guarantee that they will benefit from it after their death.

In "Immortality", the best portrayed personalised micro-immortality instances belong to Agnes. What is typical for Agnes' micro-immortality instances is that a part of them have been inherited from Agnes' father, as the character herself mentions it. There are two inter-related psycho-affective mechanisms which foster the creation and functioning of personalised micro-immortality in Agnes' imaginary. The first mechanism refers to the ontological demotion of God's intention to give life. The second mechanism refers to self-determination. To be more exact, within the first mechanism, we refer to the de-mesmerizing process involved in the man-God relationship. The Christian god of love, the one who creates man out of an overflow of Being, becomes a cold creator for Agnes, a creator which uses a programming machine to yield a human prototype. Here the reference to Baudrillard's concepts of hyperreality and simulacrum is obvious. The reality will never be a true event again in a world that has devoured its references. All that exist and will exist are already existing, multiplicated from small units, from a genetic code which replaces the totality of being (no need for a personal essence, the model suffices): "the real is produced from miniaturized cells, matrices, and memory banks, models of control - and it can be reproduced an indefinite number of times from these" (Baudrillard 1981). Thus, the Being, considered as the material involved in man's creation, is 
diminished compared to the Being traditionally represented in the creation of man, and appears only in the second phase of man's birth, when human being takes various faces generated by the prototype the Creator is responsible for.

The computer did not plan an Agnes or a Paul, but only a prototype known as a human being, giving rise to a large number of specimens that are based on the original model and haven't any individual essence. Just like a Renault car, its essence is deposited outside, in the archives of the central engineering office. Individual cars differ only in their serial numbers.

Thus conceived, the Creator is constantly absent from the life of people, as the Creator cannot (and does not want to) intervene in what happens in their life. Prayers are pointless, being as absurd as requiring the one who created the functioning mechanism of an item to be able to fix it: "That would be like praying to Edison when a light bulb burns out". Practically, God no longer has an ontological power over man, but a scientific one, in an arid sense. God's biological superiority seems to have been taken from him, as man is born out of God's pattern or template. If Kundera uses a scientific imaginary recalling Baudrillard when analysing the triggering logic behind Agnes' personalised micro-immortality, he also recycles Heidegger's theory of being cast into this world and the one of the absolute arbitrary birth (Heidegger 1962). Simulation is combined not with nostalgia - the typical feeling elicited by the postmodern divorce from references (Baudrillard 1981) - but with anxiety.

As a little girl, Agnes used to go for walks with her father, and once she asked him whether he believed in God. Father answered, "I believe in the Creator's computer." This answer was so peculiar that the child remembered it. The word "computer" was peculiar, and so was the word "Creator," for Father would never say "God" but always "Creator," as if he wanted to limit God's significance to his engineering activity. The Creator's computer: but how could a person communicate with a computer? (...) Agnes thought to herself: the Creator loaded a detailed program into the computer and went away. That God created the world and then left it to a forsaken humanity trying to address him in an echoless void - this idea isn't new. Yet it is one thing to be abandoned by the God of our forefathers and another to be abandoned by God the inventor of a cosmic computer. In his place, there is a program that is ceaselessly running in his absence, without anyone being able to change anything whatever.

By casting people unintentionally into the world, they become a board piece included in a system which yields coherent realities lacking transcendental meaning. Meaning restrains to the pure production of worlds: they are created, yet meaning can be found neither before, nor after the creation process when the functioning of the world as such begins, namely when people's lives begin. Moreover, human beings could be not only a copy of a model crafted by God - one should notice Kundera's 
Plato-like orientation when designing the mental inner-workings of his character but, a lesser degree copy, II, III, etc., if one accepts the hypothesis that the Creator's programming machine is itself determined by other hierarchically superior machines: "there is a second possibility, beyond our planet's computer there may be others that are its superiors". Kundera's appeal for Plato's philosophy, as this work is concerned, is spread everywhere and triggers permanent, inherent rifts at the level of the human being who is incapable of forming an authentic image of itself: "A person may conceal himself behind his image, he ca disappear forever behind his image, he can be completely separated from his image: a person can never be his image" (316-317), while at a meta-textual level, it displays the naivety (when linked with characters' feelings) and the paradigmatic obsolescence of such a platonic vision. The image is no longer possible in relation with human being, the reign of total opacity or total transparency has begun. In a sense, this also already indicates that immortality is rather a trap than a solution - as the latter is always structured by a positive, affirmative difference, while the former is a resigned or consumed difference.

The second mechanism is closely connected to the first one and it refers to a human being's self-determination, as man feels entitled to fabricate meaning whenever meaning is not given per se. Through self-determination, the human being compensates for God's engineering indifference towards the many individual forms of the human pattern, as the human subjects are inherently different, and are bearers of many shades, but all of them being in relation to the model which makes them possible. To express one's personality, to acknowledge oneself as an individual without which the world would not be the same, seems not a whim for Agnes, but an intelligent strategy of intellectual and psychic survival. The human being must be continuously celebrated, with passion, as a subject, and one's attachment to oneself must be socially and culturally cultivated as a means of projection when faced with existential void and the world's arbitrariness. Yet, Agnes knows that self-determination and the overrating of one's specificity in all the representations of the self are not enough to compensate for the lack of meaning (just how platonic is this!) in the world, since the instances of personalised micro-immortality are not capable of forming secure realities, producing unstable systems of signs that cannot be truly deceived:

Why all this passion? Agnes asked herself, and she thought: When we are thrust out into the world just as we are, we first have to identify with that particular throw of the dice, with that accident organized by the divine computer: to get over our surprise that precisely this (what we see facing us in the mirror) is our self. Without the faith that our face expresses our self, without that basic illusion, that arch-illusion, we cannot live, or at least we cannot take life seriously. And it isn't enough for us to identify with our selves, it is necessary to do so passionately, to the point of life and death. Because only in this way can we regard ourselves not merely as a variant of a human prototype but as a being with its own irreplaceable essence. 
It's interesting to notice that Agnes' lucid vision on her own mechanisms of representing the world, which determine the structure and the logic of her personalised micro-immortality, seems, implicitly, to deconstruct the therapeutic power (the ability to cope with one's own death and the idea of human finitude) of any constructs of symbolic immortality in general. The belief in one's own constructs of symbolic immortality is undermined by the impossibility to forget the fact that they are oriented against a Creator which does not care, a negative origin that must be eradicated as a substance, but not as a form (otherwise the idea of an origin preserves/ promotes the idea of a scope). Thus, therapeutic benefits of micro-immortalities are always diminished: at the same time when Agnes imagines various forms of symbolic immortality, she denies the safe and non-negotiable forms of death and immortality.

Perhaps death must exist. But was there no other way to arrange things? Is it really necessary for a person to leave a body behind, a body that must be buried in the ground or thrown into a fire? It's all so horrible!

The fact that Agnes' personalised micro-immortalities are triggered by the two mechanisms discussed earlier, self-determination and God's ontological demotion, means that these mechanisms actively participate in the configuration of personalised micro-immortality. They are not, as anticipated earlier, just causes of personalised micro-immortalities instances, but also fundamental vectors in their creation. For instance, demoting God from ontology to science (engineering) is clearly visible, as Agnes' micro-immortality instances tend to multiply, to exist as variants for approximately the same idea/immortality concept.

Depending on the way in which the human being is programmed (by the engineering God), Agnes believes that two immortality types are possible. In the case of an immortality type which is very similar to the life lived before death, the human being will meet the same people, will have the same experiences approximately. Practically, the immortality type which is similar to life will contain a series of permutations of events which happened in life. There will be differences at the level of shades which will not annul the relationships of the dead person with the others. What will be added is the fact that the human beings engaged in such an immortality type will interact with more people, because such a world will not be limited to their life but will include all those who lived and died before them. According to Agnes, what could be called similar immortality becomes apparent only if the Creator is responsible for our planet exclusively. Similar immortality relates to the fact that Agnes might live again by the side of her husband, Paul, and her daughter, Brigitte. It is an immortality type Agnes does not appreciate, which she fears, because she wants to experience the difference: not the similarity, but the gap, the fracture, the surprise. Moreover, what causes supplementary anguish is the fact that many dead will all be hosted by the same afterlife.

If the computer's field of activity is limited to our planet, and if our fate depends on it alone, then we cannot count on anything after death except 
some permutation of what we have already experienced in life; we shall again encounter similar landscapes and beings. Shall we be alone or in a crowd? Alas, solitude is not very likely; there is so little of it in life, so what can we expect after death! After all, the dead far outnumber the living! At best, existence after death would resemble the interlude she was now experiencing while reclining in a deck chair: from all sides she would hear the continuous babble of female voices. Eternity as the sound of endless babble: one could of course imagine worse things, but the idea of hearing women's voices forever, continuously, without end, gave her sufficient incentive to cling furiously to life and to do everything in her power to keep death as far away as possible.

Similar immortality is an immortality type which is considered just as probable as another type, different immortality. Different immortality would be a consequence of the limitation of Creator's engineering power to our planet when it is hierarchically inferior to other planets that, at their turn, have other Creators. In Agnes' imagery, the consequence of this limitation is the fact that other possible worlds still remain in the universe, worlds which await to be known, lived in by human beings after their death. In a different immortality, Agnes would not see Paul and Brigitte anymore, would not live by their side, and the thought of this gives the woman a true sensation of freedom and happiness.

In spite of this, for Agnes some variants are preferable to others (the variant in which the significant others are no longer by her side, disappear) and a privileged, desired personalised micro-immortality takes shape: a micro-immortality type that could be called ideal, and which is the one in which she stays with her father only, in a lovely landscape copied after Switzerland's mountainous landscape. This instance of personalised micro-immortality is the least discussed one, benefitting from the weakest representation in the novel and yet being the most personal. The only possible death which precedes this immortality is young Agnes's death together with the death of her father. Before losing her father, during her youth, Agnes frequently imagines that her mother chooses to save only one member of the family from an execution platoon, Agnes' sister, Laura. Her imaginary death and her father's presence make the girl really happy "her eyes were full of hot tears, and she felt inexpressibly happy to be holding her father's hand, to be with him and to die with him" (231). Agnes feels the closest bond to her father whom she resembles the most. In the hours before her un-programmed death, as a result of a traffic accident, Agnes reaches the conclusion that a way in which the Creator's programming machine can be defied is love, on condition that the feeling is real. Also, she becomes conscious of the fact that her true and only love was not Paul, but her father. Therefore, she will do everything in her power to die before Paul gets to the hospital where she is lying in a comma, while her reason and lucidity are active. The double hidden reason, coherent with Agnes' thanatic imagery, is that she does not want to say yes to further 
similar immortality, together with Paul (who is in a hurry to seal their bond with a last kiss) and that she does not want her husband to believe that he could have visually captured her in one eternal image. In other words, Agnes does not want to take Paul with her, in the next world. Neither does she want to stay by his side symbolically, in this world: the rejection of an immortality structure through others. Moreover, Agnes' gesture of denying symbolic immortality through others repeats as a loving imitation - the similar gesture of her father, who destroys his photos and his wife's photos, after her death, precisely because he does not want to become the bearer of his wife's image and implicitly, the responsible figure for her immortality. What becomes visible here is the fact that symbolic immortality is not just a simple imaginary or therapeutic figure, but a discourse where power is staged within now fragilized metaphysical dichotomies: life-death, presence-absence, keeping-letting go, memory-oblivion.

The cohabitation of a plurality of possible personalised micro-immortality instances and the privileges given to some of them point out exactly to the fight between the two mechanisms, between mistrusting the nature of the Creator and selfdetermination. As far as self-determination goes, its most clear manifestation is in the personalised micro-immortality exhibited by Agnes as that world after death where the being, freed from social constraints, can fulfil itself in an original way, as it is selfsufficient: "They're all their own creations. Everybody, so to speak, thinks himself up. But it's hard to talk about it. You cannot grasp it". It is worth mentioning that Agnes' personalised micro-immortality can only falsely be understood as immortality through art. Unlike other characters from the same novel, Bettina for instance, Agnes does not have any ambition to perpetuate her spirit in other environments than her own being. In a discussion with her sister, Laura, Agnes proves to be sarcastic at the thought, expressed by Laura, that everybody must "leave something behind". Selfdetermination is visible in the conversion of possible after-lives in chosen after-lives, a conversion which occurs in Agnes' inner landscape. Even though she exhibits both immortality types, the one similar to the real world, and the one different from it, as two probable worlds, decided by the Creator, Agnes imagines that she can freely choose between the two options. Agnes' choice is not easy. A strange traveller will visit her ward and will ask her how she wants to spend her immortality. Only two options are available: to stay with her husband and the rest of her family or spend the afterlife without them. In the end, after inner battles, she will opt for an afterlife in which her earthly relationships with the others will cease to exist. Even more so, Agnes wants to add to her different immortality an immortality with her father (a similar immortality). The two conflictual immortality types are forced to coexist and function together against the Creator and his programming machine. Against a deontologised royal sign who insists in haunting the field of consciousness. As a matter of fact, Creator or not, the presence of the Other is quite problematic in this novel, causing anguish and acting as a negative trigger in dissolving the powerful discourse 
of immortality, may it be a symbolic micro-immortality or a symbolic immortality through the Other (children, posterity, etc.).

\section{The Other as main obstacle for immortality}

Kundera's immortality is inseparable from the Other and from its negative effect on people which anticipate or experiment symbolic immortality. It is a perpetual obstacle which comes between the being and its dreamt, lived or feared immortality. Kundera's negative Other does not completely dissolve immortality for instance, Agnes' similar micro-immortality preserves Paul and Brigitte - but it makes it unbearable and reduces its self-manipulative effect, since it always causes an ontological wound. The way in which Kundera pictures the Other in this novel goes against the current trend which understands it as an object of pleasure, a commodity seen in an exclusive positive light (Han 2014, Javeau 2007, Lesourd 2007, Deloro 2009). Kundera's otherness owes a great deal to Jean-Paul Sartre's philosophy. For both the Czech writer and the French philosopher, otherness is a matter of ontological conflict. Each subjective entity tends to transform other beings in objects, to reduce them to their very own structures of being-in-itself in order to rule over them and keep itself sheltered from their freedom. One's freedom annuls the Other's freedom. This happens at a glance. The Sartrean look has an incredible force, as it is an excessive engagement of the sight sense (Doubrovsky, 1989, 161). For Sartre, the look must be strong enough to defeat the Other, because the Other is everywhere: its body can be traced back to any object, any tool which reveals the proper use as set by the Other (Sartre, 1943, 381) who aims at the dissolution of the being-for-itself into the being-in-itself. Sartre's phenomenological look can also be a matter of hearing (Sartre, 1943, 316), and touch (Sartre, 1943, 429). Moreover, there should be no connection established between sight and eye, because when the Other's sight is pointed at one, the sighted object remains separated from the object which makes the sight manifest (316). In phenomenological terms, the look the Other casts over me transforms me in an object and tends to pull me away from my own being (Sartre, 1943, 572).

Kundera allows his text to be permeated by this Sartrean interpretation of otherness not purely in an existentialist key, but also in conjunction with a deconstructive direction. Its negativity derives not only from an existential approach of the world, but also from the untamed and tameless nature of Other that a significant part of contemporary socio-humanistic discourses tries to suppress, proposing an alteritary heavenly figure with no ontological density, where all differences are not dead and buried, but had never existed, while the whole history of differences between human beings was only an illusion caused by communication (understood as the lightweight coat of language). As Cyrille Deloro highlights: "The Other has become a commercial slogan: love one another, the Other 'is good for you' ... but this is not true. The more we pacify our relations, the less the Other exists" (Deloro 2009). This way of configuring a reality where differences are dehydrated by an independent and powerful eye that 
finds its orbit and all potential roots and shelters to be obstacles, while delivering itself to a totally open space - forms and concepts can be easily taken as synonyms is also to be found in the academic vogue of the positive death movement (death is natural and should be accepted and embraced both individually and socially) or in the social theories that extend the cultural desiderata of the inclusion of the elders to the necessity to cope with old age either in terms of age is just a number (a social construct for which there is no need; old age does not really exist) or in terms of ageing is part of your life story (a narrative construct for which there is a terrible need; old age is aestheticized).

Coming back to Kundera's novel, the Other puts into question not so much the postmodern continuity - generated by the simulated reality and its genetic multiplication of patters and not by a platonic-like reality - but its ideological instrumentation as an ontological revival and, thus, as (im)possibility for immortality. Also, Kundera's Other corrodes the more classic cultural dream of enduring, of gaining the right to never let go History. The Other is perceived as an obstacle for immortality in two important instances. The first instance refers to the Other as imaginary projection within personalised micro-immortality. The second instance refers to the Other as a receiver of the human being's immortality (as immortalical support), when participating in the setting of symbolic immortality structures: immortality through art especially, and the immortality achieved through children or posterity as well. While the second instance will be discussed in the next chapter, let us recall that, as far as the first instance of the Other is concerned, its obstacle-nature for immortality has already been noticed in the chapter concerning personalised micro-immortalities.

The presence of the Other within personalised micro-immortality is not desired, it is actually feared. Similar immortality, the one spent with dear ones, far from being a happy one, is quite resembling the afterlife described by Sartre in No Exit, an afterlife based on the obligation to stay forever together with an incompatible Other, and, moreover, dangerous in itself. Agnes does not want to see Paul, her daughter or her sister, Laura. Family life drastically limits her possibilities of being alone, situation which she perceives as painful and which she tries to counteract through moments of short solitude, for example when she uses the elevator. The same can be said in her relation to her own sister, Laura. Laura copies her sister's gestures, opinions, tastes, from childhood up to adulthood and falls in love with Agnes' husband. After Agnes' accidental death, Laura will fulfill her dream and will marry Paul. A good Sartrean demonstration of the idea that the dead fall as prey to the Other, which takes advantage of their total lack of freedom; to be dead means "être en proie aux vivants" (Sartre, 1943, 588).

The novel also contains a representation of the Other which is apparently antiSartrean: the one in which the Other, who is dead, appears as a force capable of taking control over and of poisoning the ones left alive. This time, the one who has less being and who is weaker is the one who lives, not the one who dies. This is a false 
anti-Sartrean representation, a matter of perspective and shade. For Sartre the dead is the weak part because the Other is identified more to the living and for Kundera, it is only in this particular instance that the dead one is the Other.

She doesn't want to vanish. She is thinking of suicide because she sees it as a way to stay. To stay with him. To stay with us. To engrave herself forever on all our memories. To force her body into our lives. To crush us. (176)

The only exception to the negative image the Other has for Agnes is her father, a man "tired" by others, which he erases from his life (the scene where he destroys his photos and those of Agnes' mother) and whom he doesn't want by his side in his last moments (he wants not to be looked at when dying). Her father is the only person Agnes wants to keep from similar micro-immortality so that it may accompany her in the different micro-immortality. The father is not an obstacle because he shares the same drive as Agnes: the will to abandon humanity. This abandonment, social and ontological attitude with obvious Sartrean echoes, translates through a deep mistrust in the idea of living with others. For Agnes, otherness presupposes a continual form of aggression ("looks were like weights that pressed her down to the ground, or like kisses that sucked her strength; that looks were needles that, etched the wrinkles in her face"), whether it manifests itself through the eyesight of others attacking her face, which she must avoid at all cost ("the most important thing was that nobody looked at her"), or through a massive bodily presence which makes space crowded and determines her to feel useless and powerless:

people didn't get out of her way. She was aware of it, she felt it to be her misfortune and often tried to overcome it: she tried to gather courage, to walk bravely ahead, to stick to her path and force the oncoming person to give way, but she never succeeded. In this every day, banal test of power she was always the loser. (22)

The fact that Agnes shares the same metaphysical desire to abandon the others a desire which does not lack in suicidal impulses - allows her to integrate her father inside her own being as alter-ego, alongside which she can dream of a personalised micro-immortality which can gratify her in her fantasies. At the same time, Agnes' dream of spending her old age away from her family, in a house in Switzerland, thinking of her dead father is an anticipation of her privileged micro-immortality, or, conversely, the micro-immortality she wants is a continuation of her dream to exile herself, an idea which becomes recurrent in her last years.

If we tackle the importance of the face and the place it occupies in Agnes' imagery (and, by extension, Kundera's), the reason why Agnes does not want to be looked at by Paul before she dies has to do with her own will of getting rid of her own face by not allowing others to capture it or fix it in their memory. This can be translated as the ultimate fear of symbolic immortality through Others. The others falsify the being more than they preserve it - metonymically reduced to the 
face - and performs it intentionally and cannibalistically. In addition, the process takes place inside the temporal frame, so that the experience becomes virtually infinite and dynamic (repetition that bring continuous, but never total change): "Immortality means eternal trial".

The face that will disappear tomorrow under the earth or into the fire does not belong to the future dead but purely and entirely to the living, who are hungry and need to eat the dead, their letters, their money, their photographs, their old loves, their secrets. (251)

Another possibility is that immortality through Other is not a normal, immediate continuation of death, but that it is triggered, after a certain time after death, by various forms of otherness. Such an immortality worries Agnes:

she could not rid herself of anxiety because one second of her life, instead of dissolving into nothingness like all the other seconds of life, would remain torn out of the course of time and some stupid coincidence could make it come back to haunt her like the badly buried dead. (31-32)

Although in Kundera's novel, the continuation carried out through the Other is undeniably of Sartrean origins, as already discussed, it can also be associated to a profoundly postmodern meaning. All the characters have a true obsession for the Other's look, a sight which is frequently transformed in institutionalized sight, becoming more socio-political and less ontological in nature. This is a generalized sight, a consequence of two large co-dependent postmodern phenomena: the will to exhibit one's image (exhibitionism) and the necessity to interact with as many images as possible (voyeurism): "God's eye has been replaced by a camera. The eye of one has been replaced by the eyes of all. Life has changed into one vast orgy in which everyone takes part" (31). These phenomena produce a rhizomatic configuration of the Other: always plural, always connected with others. Moreover, the memory of the Other, terrifying for the one who desires to be the author of the traces left in the world, seems to be enhanced by the memory of photographic cameras and recorders; this memory seems to refer to the mandatory electronic memory of the Internet ${ }^{4}$. However, symbolic immortality is not linked to the era of technology and, in this sense, Kundera's vision can be seen either as neo-metaphysically articulated (new and old images are produced by reality) or as postmodern (simulation has the same historical age as reality, and it was only dormant until technology has been invented):

has the character of immortality changed in the epoch of cameras? I can answer that without hesitation: essentially, no; for the photographic lens had existed long before it was invented; it existed as its own non-materialized essence. Even when no lens was aimed at them, people already behaved as if they were being photographed. (51) 
Moving on to the next chapter which will analyze the means of deconstructing immortality through art, with reference to immortality through posterity, we must notice that personalised micro-immortality is meant to fail from the very start. Compared to the immortality structures (through others, through art, or through nature) which, as mentioned above, imply, as is the case of Kundera, the absence of an ending, micro-immortality cannot fulfil its own need to become permanent. The explanation is that micro-immortality cannot stand against symbolic immortality structures since it is weaker from the point of view of continuity and durability in time. No matter how much human beings would work on their immortality, it will not continue after their death, it will be forgotten, or, in the best of cases, it will be assimilated as part of a symbolic immortality structure (therefore, by another consciousness) within which it will be changed: "even though it is possible to design, manipulate, and orchestrate one's immortality in advance, it never comes to pass the way it has been intended" (80). This is a lesson learnt by people who plan for an immortality type which caters for their own taste and which will end up imprisoned in a hilarious ${ }^{5}$ immortality or the case of Goethe - who is a character in Kundera's novel - when he notices that his micro-immortality (on whose content the reader learns nothing) will never be achieved because of Bettina, his lover-child who will manage his immortality.

\section{Deconstructing symbolic immortality through art}

For Kundera, immortality through art is a symbolic immortality structure longed for by artists (writers, poets, etc.), the Romantics especially, because of the lengthy existence, throughout history, of a social and artistic code which supposes the exaltation of self transcendence:

They all lived in transcendence, they surpassed themselves, stretched their arms far out into the distance, to the end of their lives and far beyond their lives, to the outer reaches of nonbeing. And as I have already said, wherever there is death there is also immortality, her companion (65).

Immortality through art - one of the major symbolic immortality structures (alongside immortality through nature and art/posterity) - is deconstructed by Kundera by exposing the Other to a negative light. A great part of the deconstruction - understood as means of criticizing the fixed nature of the various meanings accumulated within the symbolic immortality concept throughout time - is done in relation to the story regarding the Goethe-Bettina relationship (characters which can be easily traced back historically), but also in relation to the story of a painter called Rubens, less similar to the real character, placed in a different historical time than Peter Paul Rubens ${ }^{6}$ the painter. Bettina is a woman who is 26 years younger than Goethe, the daughter of a former lover of the German writer, who tries to seduce him by adopting a dual attitude: child-like and teenage-like (Lolita-like). The Bettina and 
Goethe relationship, a relationship at a distance for the most part, takes place over the course of many years as a sort of friendship with love implications, quite intense at times, which Goethe constantly tries to avoid but which the woman obstinately cultivates. There are tense moments, like the episode when Bettina smacks Goethe's wife's glasses to the ground or the only erotic episode of their relationship, the one in which Goethe touches her breasts. Bettina gets close to Goethe's mother, trying to find details about his life, writes him tens of letters, and will write about him after he dies. As Kundera clearly points out - an eternal commentator of the acts of his characters and the relationship between them - the Goethe-Bettina relationship is not intended to reach love, may it be shared by both or not, but immortality: "What was at stake between them was not love. It was immortality" (61).

Bettina is the main character of the novel who, in relation to Kundera's theory of negative otherness (and the many textual examples therein), functions as an agent of deconstructing immortality through art. At the same textual level, Rubens is another instance of this deconstruction process, whereas at the meta-textual level, we can place the narrator himself. The deconstruction of symbolic immortality is set on stage by representing the consequences of the relationship with the Other: confiscation and parasitic processes on the one hand, and hyper-conservation and double absence on the other hand.

\section{Confiscation and parasitic processes}

Bettina is a genuine immortality hunter. She wishes to tie her name to the name of a person with a high potential of becoming famous through the art they created (literature, music, either of them). She will try, not only with Goethe, but with others as well, like Beethoven, to earn a place in immortality. To fulfil this purpose, Bettina resorts to two main strategies, closely connected to one another: confiscating the Other's immortality and submitting it to parasitic processes. The confiscation process refers to the attempt of managing the immortality through art/literature of another person, namely Goethe, who is convinced that he is the one taking care of his artistic immortality: "He considered himself the administrator of his immortality" (72). Parasitic processes refer to inserting representations of the self in the same symbolic immortality through art which actually belongs to another person. If we strictly refer to Bettina ${ }^{7}$, confiscation would be the form through which she wants to handle a symbolic immortality which is not her own (through literature), while parasitic processes would be the content of this confiscation, namely what Bettina does with symbolic immortality after confiscating it. She infiltrates inside this immortality. She cannot eliminate the original content, namely Goethe, but she may join him/it, and may manifest as symbolic presence.

Bettina continually fights to win a place in Goethe's immortality in order to manage it as she sees fit. This is a difficult battle which, as mentioned earlier, takes place over the course of many years, and which involves a lot of perseverance from 
the woman: "Bettina did not feel disarmed and had no intention of giving up her battle. Understand me well: not a battle for love; a battle for immortality" (64). Besides the fact that she writes 49 letters to which Goethe answers now and then, letters in which she talks to him about love only (and whom she threatens not to throw), Bettina draws a statue sketch of Goethe (on paper). This happens because Frankfurt's town councillors decide to erect a monument for Goethe, which Bettina dislikes. As Kundera points out, this is the ultimate, unambiguous declaration of her interest in Goethe's immortality: "By her drawing, Bettina characterized for the first time in an unambiguous way what the game had been all about from the beginning: immortality" (68). For Goethe this is an epiphany: he undoubtedly understands that Bettina wants to confiscate his immortality: "she was the one to sew the ceremonial shroud in which he would be exhibited to posterity; and that nothing he could do would stop her" (68). The discovery drives him mad and makes him more prudent in his relationship to Bettina, trying to keep her away, to be able to watch over her better. He doesn't want her love, but neither can he risk throwing her away because he knows that it might have a negative impact on his immortality.

The more she feels that Goethe's death is approaching, the more intense the fight for immortality becomes, so that, towards the end of his life, she is able to take control over it: "Bettina was about to take Goethe's immortality into her own hands" (73). The imminent death of Goethe determines Bettina to feel that she loves Goethe more intensely, a feeling which is quite false (it becomes obvious for the readers and Kundera also points this out). Actually, love is just the rod with which Bettina captures Goethe, her reason for taking full possession of his immortality:

the older he got, the more attractive he became, because the closer he was to death, the closer he was to immortality. Only a dead Goethe would be able to grasp her firmly by the hand and lead her to the Temple of Fame. The closer he was to death, the less willing she was to give him up. (65)

Confiscation and parasitic processes are fulfilled when Goethe dies. Bettina can then finally publish the book which reveals and falsifies her relationship with Goethe, a relationship built for the purpose of the book, and which the woman considers a trampoline for her own immortality. Bettina's book represents a tribute to Goethe whose image is manipulated for her own benefit, but it represents, at the same time, her revenge act against the rejection she felt from Goethe during his lifetime:

that book is at the same time (and to a much greater extent) a lesson in love given to the dead poet, who on coming face-to-face with great emotion behaved like a cowardly philistine and sacrificed passion to the miserable tranquillity of marriage. Bettina's book was at the same time an homage and a thrashing. (76)

What is certain is that Bettina manages to secure a place in posterity because of confiscating Goethe's symbolic immortality through art: even though her fight - or, 
what Kundera calls "the gesture of longing for immortality" - towards reaching this goal takes place over a very large stretch of time, Goethe must die for this to come true. Kundera's vision of the dead is definitely Sartrean. For Sartre, the dead person is the vanquished person, who lacks in freedom, who becomes an object, part of the phenomenological game of the sight which the Other addresses (Sartre, 1943, 588). In Kundera's book we find the same presence of the dead's complete weakness, of his inability to defend himself in the face of the posterity who takes hold of the artist. Death extracts the being from the $\operatorname{man}_{L}$ and the others continue the process by attacking the dead person's immortality:

In the hierarchy of age, the baby has the highest rank, then the child, then the adolescent, and only then the adult. As for the old, they are virtually at ground level, at the very bottom of this pyramid of values. And the dead? They are under the ground. Even lower than the old. The old are still accorded human rights. The dead, however, lose all rights from the very first second of death. No law protects them any longer from slander, their privacy has ceased to be private; not even the letters written to them by their loved ones, not even the family album left to them by their mothers, nothing, nothing belongs to them any longer. (250-251)

The same unavoidable confiscation of immortality by the Other is subtly captured by the narrator-commentator when placing immortality through art in the descent of a general immortality which everybody benefits from: immortality through posterity: "Everyone can achieve immortality to a smaller or greater degree, of shorter or longer duration" (48). The main difference between immortality through art and immortality through posterity has to do with the breadth and length of immortality: immortality through art theoretically lasts more than immortality through posterity and is wider than the latter, namely it is known and built by a large number of people, similarly to the immortality of state people. Yet, neither the length, nor the breadth are guarantees of the fact that immortality through art will not be confiscated.

Naturally, when it comes to immortality people are not equal. We have to distinguish between so-called minor immortality, the memory of a person in the minds of those who knew him (the kind of immortality the village mayor longed for), and great immortality, which means the memory of a person in the minds of people who never knew him personally. There are certain paths in life that from the very beginning place a person face to face with such great immortality, uncertain, it is true, even improbable, yet undeniably possible: they are the paths of artists and statesmen. (49)

In addition to the textual level of confiscation and the parasitic processes against immortality through art, already discussed, there is a meta-textual, reflexive level: the scenes where the novel focuses on conversations on topics such as art, personal life and immortality between Goethe and Hemingway. A strange couple of writers 
intentionally chosen by Kundera to demonstrate the arbitrariness of immortality, especially of the one achieved through art: nobody knows whose company one will share after death and nobody can manifest resistance to a companionship with the Other which is unwanted and unknown. This post-mortem ontological (Sartrean, to think only at No Exit) weakness, already discussed, might be in some ways, Kundera suggests, more significant for writers and artists than for other people.

they don't belong together at all, they have nothing in common! So what? With whom do you think Goethe would like to pass his time in the other world? With Herder? With Holderlin? With Bettina? With Eckermann? (...) It was therefore only out of my most sincere love for him that I dreamed up someone at his side who interested him very much (in case you have forgotten, let me remind you that Goethe was fascinated by America throughout his life!), someone who wasn't like the band of pale-faced Romantics that came to dominate Germany toward the end of his life. (85)

Not only Goethe, but, generally speaking, any writer, artist is confiscated and manipulated by his posterity. Interpretation is historical, cultural, unpredictable, unstable and anti-human(ist) when thinking that it does not have to do justice to a person's need of self-narrative, meaning and identity. As serious as the stakes of such a scene may be, the more hilarious it is, in some way, its construction, when Goethe confesses to Hemingway that he chose a marred face after death, to be able to run from Bettina, who follows him there as well, angry with him, or when both writers laugh and are engaged in discussions which are partially intimate, partially philosophical. For this meta-textual demonstrative confiscation of immortality through art to be even more obvious, Goethe himself notices that both him and Hemingway do not have an ontological nature, do not dwell in the desired micro-immortality, and do not consume their own immortality instances through art, but are textual constructions of the author's novel: "You know perfectly well that at this moment we are but the frivolous fantasy of a novelist who lets us say things we would probably never say on our own" (215).

Kundera puts forward the idea that a writer's immortality is not constant in time. The contemporary era is more interested to read about the life of that writer than his work. A writer's work is seen as a life code, as meaningless as any other's. It is the illustration of a sort of envy of the ones who benefit from a minor immortality in the face of those benefitting from an extended (major) immortality and of their avenging gestures which shift the interest of the reading process from the work of a writer to his biography. In this perspective, interpretation regains a sort of humanness in the sense that it reveals itself as always triggered by humans, for their own pleasure and need of soft, common, easy narrative and meaning, while at the same time, it is anti-human(ist) because it elicits the death of the author in a radical, non-symbolic manner, opposed to the death of the author conjured by Roland Barthes (1967) as 
a way of liberating the meanings of a text from the tyranny of a God-like author, a way of de-theologising them. In Kundera's novel, the author dies not in order to release signs and meanings, but in order to release references, to rearticulate the reality of the author's biographical person obliterated by their creation. There is a subtle yet powerful difference between the conceptual places where the auctorial death is produced. For Barthes, the author must cease to exist within their works, they are detached from their creations for their creations, while Immortality pictures the death of the author away from their creations, but with their creations (they die simultaneously and separated). Nothing is resurrected after the second death, which is fallowed only by a crowd (readers that do not have to read, formal readers) rejoicing for the trivial (and temporary) come back of the reference.

Europe reduced Europe to fifty works of genius that it never understood. Just think of this outrageous inequality: millions of Europeans signifying nothing, against fifty names signifying everything! Class inequality is but an insignificant shortcoming compared to this insulting metaphysical inequality, which turns some into grains of sand while endowing others with the meaning of being! It was necessary to say out loud at last that reading about Hemingway is a thousand times more amusing and instructive than reading Hemingway. It was necessary to show that Hemingway's work is but a coded form of Hemingway's life and that this life was just as poor and meaningless as all our lives. (335-336)

\section{Hyper-conservation and double absence}

Hyper-conservation and double absence are the other pair of consequences of the relationship with the Other which Kundera uses to deconstruct the symbolic immortality through art. The most intense literary representations can be found in the conversations between Goethe and Hemingway, but these are present in other episodes as well. If confiscation and the parasitic processes begin during the life time of the owner of the symbolic immortality, hyper-conservation and double absence appear after the death of the consciousness of the ones who lived in expectation of their immortality through art. Apparently, the two are conflicting consequences, but the truth is that they are two sides of the same coin. Hyper-conservation refers to the fact that, after death, the artist is completely assimilated by posterity via his work. Such a perspective is considered undesirable by many of Kundera's characters, not necessarily only by the ones obsessed by the idea of immortality through art: "no greater punishment, than turning a second into eternity, tearing someone out of the flow of time" (294). This is not equivalent, as noticed above, with saying that the artist finds his immortality in his work. Posterity wishes not to unravel the meaning of a writer's work, but the meaning of a writer's life, through and against their work.

The hyper-conserved artist is, at the same time, the artist which suffers from double absence, simply because nobody needs a writer's presence or, even more 
radically, their haunting. On the one hand, he loses his freedom, post-mortem, because they cannot choose anymore, and, on the other hand, because he cannot manifest themselfves in the world, as true presence, despite the greater or lesser success of their work. The clearest absence of freedom is the impossibility to commit suicide (a radical form of holding on to life), as Hemingway's character notices:

A man can take his own life. But he cannot take his own immortality. As soon as immortality has you aboard, you can't get off, and even if you shoot yourself you'll stay on deck along with your suicide, and that's horrible. (82)

For Goethe, to no longer be able to manifest oneself as a worldly presence implies a lengthy and painful process of acceptance, with great chances of never being finalised. What he tells Hemingway, in this regard, seems to bring the contemporary criticism of death denial to the forefront (Ariès, 1974; Gorer, 1967):

Even after death it was hard for me to accept the idea that I no longer existed.

To be mortal is the most basic human experience, and yet man has never been able to accept it, grasp it, and behave accordingly. Man doesn't know how to be mortal. And when he dies, he doesn't even know how to be dead. (215)

It is still Goethe who explains to Hemingway (quite ironically) that immortality through art, although desired by Goethe, is closer to illusion than to reality. That is because reality involves presence. Conversely absence is a sign of withdrawal from reality. The work of writers is what remain and not a form of writers' consciousness. The writer who had hoped he would be remembered through his work was wrong. He does not dwell in them and cannot be found in them. The way in which Goethe sets the artist apart from his creation represents one of the most powerful means of criticising symbolic immortality through art in this novel:

exercise your brain: he who doesn't exist cannot be present. Is that so complicated? The instant I died I vanished from everywhere, totally. I even vanished from my books. Those books exist in the world without me. Nobody will ever find me in them. Because you cannot find someone who does not exist. (214)

Goethe gives Hemingway the lesson of being absent from the world, as he teaches himself the lesson of hyper-conservation. He seems to learn, during the conversation he has with his writer friend, that hyper-conservation spares him from thinking of personal immortality. The immortality of his work/life as a work or product continues without him, so that he feels ready to relish the silence of non-existence. From a critical theoretical perspective, these observations condense Kundera's long - and deconstructive - goodbye to symbolic immortality: there is no need to abandon it, no possibility to destroy it. Both the individual and cultural impulses towards immortality would remain haemorrhagic and the problem is elsewhere. In what society, literature and culture does with the unsettling substance of this drive for enduring, transcending, 
having all while being the same, going everywhere while contemplating the roots, or perhaps, the other way around - exactly what Kundera's novel is tackling. In such a context, restoring death's capacity for symbolic exchange (Baudrillard again, this time his work from 1976) and going to sleep in spite of immortality's permanent, synthetic light, would suffice.

I have come to the definite conclusion that the eternal trial is bullshit. I have decided to make use of my death at last and, if I can express it with such an imprecise term, to go to sleep. To enjoy the delights of total nonexistence. (216)

\section{Notes}

1 Avatars of possibilities and cultural legitimations of symbolic immortality can also be found in today's discourses of entitlement (Foley 2011) - which articulates the vast majority of the most praised parenting theories and practices of our times -, subtly and dialectically connected with the 'fear of insignificance' (Stenger 2010).

2 Actually, in an interview from 1989, Kundera manifested his disagreement with Sartre's manner of subordinating literature to philosophy, to ideas, opposing literary meditation (id est meditating through literature, not within literature) to philosophical novel.

3 In recent contemporary fiction, David Eagleman (2009) provides the an impressive collection of personalised immortalities.

4 Yet, this is anticipated by Kundera since the Internet reality of 1990, the year the book was published, is not the same as the one in 2000.

5 "A man longs to be immortal, and one day the camera will show us a mouth contorted into a pathetic grimace-the only thing we will remember about him, the only thing that will remain as a parabola of his entire life. He will enter a kind of immortality that we may call ridiculous" (50). Hilarious immortality is, according to Kundera, an immortality which is lurking in the dark for us all.

6 I will not dwell on the deconstruction of the artistic, symbolic immortality dedicated to Rubens. However, I would like to mention that it is done by directing Rubens away from art and by quenching his immortality endeavours. Rubens realizes that to desire immortality through art is a sign of ambition and self over--appreciation.

7 Napoleon, for instance, another character with historical underpinnings in Kundera's novel, does not try to confiscate, when he meets Goethe, hoping that this meeting will remain as part of history and will strengthen his immortality through posterity (the presence of art and literature), but who resorts to parasitic processes, linking their name to Goethe's.

\section{Works Cited}

Ariès, Philippe. Western Attitudes Toward Death: From the Middle Ages to the Present. Translated by P. M. Ranum. Baltimore \& London: The Johns Hopkins University Press, 1974.

Barthes, Roland. The Death of the Author. http://writing.upenn.edu/ taransky/Barthes.pdf. 1967.

Baudrillard, Jean. Simulacres et simulation. Paris: Editions Galilée, 1981.

Baudrillard, Jean. L'échange symbolique et la mort. Paris: Gallimard, 1976.

Bauman, Zygmunt. Mortality, Immortality, and Other Life Strategies. Cambridge: Polity Press, 1992. 
Berger, Peter L. \& Luckmann, Thomas. The Social Construction of Reality: A Treatise in the Sociology of Knowledge. Garden City, NY: Doubleday, 1966.

Deloro, Cyrille. L'autre. Petit traité de narcissisme intelligent. Paris: Larousse, 2009.

Derrida, Jacques. Apories. Mourir - s'attendre aux « limites de la vérité ». Galilée, 1996.

Derrida, Jacques. L'écriture et la différence. Paris: Éditions du Seuil, 1967.

Doubrovsky, Serge. Le livre brisé. Paris: Bernard Grasset, 1989.

Eagleman, David. Sum. Forty Tales from the Afterlife. New York: Pantheon Books, 2009.

Eco, Umberto. Six Walks in the Fictional Woods. Cambridge: Harvard University Press, 1994.

Foley, Michael. The Age of Absurdity: Why Modern Life Makes It Hard to Be Happy. London: Simon \& Schuster, 2011.

Geuss, Raymond. The Idea of Critical Theory. Habermas and the Frankfurt School. Cambridge University Press, 1981.

Gorer, Geoffrey. Death, Grief and Mourning. New York: Anchor Books, 1967.

Han, Byung-Chul. Agonia erosului şi alte eseuri [The Agony of Eros and Other Essays]. Translated by V. Nişcov. Bucureşti: Humanitas, 2014.

Harari, Yuval Noah. Homo Deus. A Brief History of Tomorrow. Vintage, 2017.

Heidegger, Martin (1962). Being and Time. Translated by J. Macquarrie \& E. Robinson. Blackwell Publishing, 1962. (Original work published 1927).

Javeau, Claude. Les paradoxes de la postmodernité. Paris: Presses Universitaires de France, 2007. Kundera, Milan. Immortality. Translated by Peter Kussi. New York: Harper Perennial, 1999.

(Original work published 1990).

Lesourd, Serge. "La mélancolisation du sujet postmoderne ou la disparition de l'Autre", Cliniques Méditerranéennes. 1(75), 2007, 13-26.

Lifton, Robert J. \& Olson, Eric. Living and Dying. Wildwood House, 1974.

Lifton, Robert J. The Broken Connection: On Death and the Continuity of Life. Simon \& Schuster, 1979.

Oppenheim, Lois. "A Conversation with Milan Kundera", The Review of Contemporary Fiction. Summer 1989, vol. 9, no. 2.

Sartre, Jean-Paul. L'être et le néant. Essai d'ontologie phénoménologique. Paris: Gallimard, 1943. Strenger, Carlo. The Fear of Insignificance: Searching for Meaning in The Twenty-First Century. London: Palgrave/Macmillan, 2011. 